\title{
CROSS CULTURE UNDERSTANDING IN EFL TEACHING: AN ANALYSIS FOR INDONESIA CONTEXT
}

\author{
ANDRI MAULANA \\ University of Lucknow, India \\ Andrimaulana8@gmail.com
}

DOI : http://dx.doi.org/10.29300/ling.v6i2.3460

Received: July 29th 2020

Accepted: November 26th 2020

Published: December 3rd 2020

\begin{abstract}
This study attempts to elaborate on the importance of cultural understanding of English foreign learners' communicative competence. In the English language teaching in Indonesia, the role of culture is a crucial thing which needs to be combined with the teaching material to assist teachers and students for reaching the learning objective. Based on the findings of some studies, English learners in Indonesia face several obstacles when they find some terms which are unable to get its point in the literal meaning. Understanding the background culture in learning English is expected to minimize students' misunderstanding and lead them to use proper English in real communication. Integrated teaching material which contains cultural contents and its backgrounds is one way to introduce English to the learners, not only as a language but as a culture as well. Providing topics of learning based on authentic sources from native English speaking countries such as fable, short story, conversation role-play, songs, and movie. Arranging integrated teaching material that covers listening, speaking, reading, and writing with included cultural or arts contents of English native speakers. The teacher should not only teach students in linguistic competence but should teach them communicative competence as well because mastering linguistic competence is insufficient to use English in natural discourse. The appropriateness of English in use toward communication context is the objective of understanding the culture and language.
\end{abstract}

Keywords: Culture understanding, Teaching Material, Communicative Competence, EFL.

\section{INTRODUCTION}

English as Foreign Language (EFL) learners in Indonesia are strived to understand the target language both in literal and contextual meaning while they are attempting to study its language. They may get difficulties, for instance, when they find some vocabularies which have different meaning depending on its context. For EFL learners, they probably get similar obstacles during their learning period. This problem may appear due to a lack of understanding of the complexity of language. English learners are not only required to know the translation of some words or sentences but also some other aspects related to it. In some cases, some English vocabularies are unable to be translated to the target language directly and vice versa. For example in the context of Bahasa Indonesia and English, the word 'shrugs' means expression to show that a person does not know about something by rising his/her shoulders. This is an example that this word is tough to be found in its translation in How to cite this article: Maulana, A. (2020). Cross culture understanding in EFL teaching: an analysis for Indonesia context. Linguists : Journal Of Linguistics and Language Teaching, 6(2), 98-106. doi: http://dx.doi.org/10.29300/ling.v6i2.3460 
Bahasa Indonesia. This happens because in Indonesian culture, mostly the people express this feeling by shaking their heads. Another example in a different case is the differences between British and American use of the word 'check'. In British usage, the word refers to the act of examining something, but in contrast, that word could refer to a paper that instructs the payment In American usage. In this case, the understanding of culture and society's behavior regarding the target language is definitely required by English learners, because culture, society, and language relate to one another.

The relation among language, society, and culture is illustrated by Saphir-Whorf Hypothesis which is known as the "Theory of linguistic relativity". The main idea in this hypothesis, as Whorf (Whorf, 1952, 1956; Levinson, 2000; Gilbert, et al. 2008) puts it, is that every human being views the world by his own native language (Jafari, 2012). It means that the way people think, utter, and behaviors are influenced by culture, society, and geography. Society has their own habit and creates some rules and customs which construct the people mindset and influence the people's point of view. According to Roohul-Amini (1989), Elements such as language, rituals, clothes, science, beliefs, and values connect people together (Afriani, Z.L; Mirizon, S; Sitinjak, 2020; Jafari, 2012). These elements make a society is unique and has its own special characteristics because it has been arranged as the time is going on. The people are doing the same things gradually and inherit it to their generation unconsciously. This is in line with Edward Sapir (1956) statement; that culture is a system of behaviors and modes that depend on unconsciousness (Jafari, 2012). These backgrounds also caused language variation among societies from different places with their own uniqueness, so the language learner should understand the background of the native speaker of its language they learned.

Further, language as a part of culture has a crucial role to construct the image of society. Language becomes a medium to express people's feelings and thought. This statement is strengthened by Larsen-freeman \& Anderson (2011) that "Culture is the everyday lifestyle of people who use the language". In addition, in English learner context, they may face confusion toward native speaker speaking style; in spoken English most of the people utter in both formal and informal ways which probably appear idiomatic sentences, proverb, or English slang. These particular language styles are not able to be translated directly into literal meaning, because the sentence or the term has a specific meaning. According to Hyms (1971) as cited in Larsen-freeman and Anderson (2011) being able to communicate requires more than linguistic competence; it requires communicative competence, Communicative competence is Knowing when and how to say what to whom. Linguistic competence may cover linguistic units such as grammar structure, vocabulary items, and functions, while communicative competence is "appropriateness" as Hymes LInguısıs: Journaı or LInguıstıcs ana Language ı eacnıng Vol. 6, No. 2, December 2020 
(1980) argues that "appropriateness" is a "universal of speech", related to the social codes of speech communities, what he refers to "shared understandings of rights and duties, norms of interactions, grounds of authority, and the like" (Nunn, 2002).

Therefore, the learners' understanding of English society's background is also required, because when students only learn about linguistic competence, it will be an imbalance. This thing indicates that the term for a specific thing or expression has a close relation toward a society who creates these languages form based on their culture. For example, the sentence 'An apple of my eyes', the sentence does not mean as a fruit, but rather than an image of someone beloved. Another example is 'Head and Shoulders', this expression is not a physically head and shoulders as a part of the human body, but the implicit meaning of this sentence is an expression of something best. Therefore, English learners should understand some language terms related to the culture, so they will be able to understand the meaning of those sentences and minimize misunderstanding whether in written or spoken form.

On the literary works, arts, and histories, whole elements of culture such as socially transmitted and common behavior patterns, institutions, beliefs, and all other products of human works and thought are there, therefore, these elements need to be contained in integrated teaching material and introduced to the English learner to learn the language in a complex package. It may assist them to easily understand the language in linguistic and communicative competence.

\section{METHODOLOGY}

This study uses a qualitative method with the study of literature (documents) from several sources both print and electronic media, as well as books, journals, and scientific articles. Based on the search results obtained and selected data that meets the criteria. Analysis of the literature review includes data collections, data reductions, data presentations, and conclusion. This study attempts to elaborate on the importance of cultural understanding of English foreign learners' communicative competence. On the other hand, the aims of this study also to be a reference for English language teaching in Indonesia.

\section{English learners' Problems in Indonesia on culture understanding}

English has several language forms that have a specific meaning. The essence of its meaning will not be gotten if those forms are translated directly to another language in the literal meaning. It may be grammatically correct but does not get its exact meaning. For example proverb, idiom, and phrasal verb are English forms that cannot be translated word by word because of those forms rather figurative language. These forms may be a complicated 
form to be understood. So the explanations regarding the background of those forms are definitely required by students to make it clear and also applicable in natural discourse. Another problem is in the real situation of English communication, Indonesia students face unpredictable topic question or probably it is unfamiliar to them. Lack of vocabulary of its topic may be one problem to them, sometimes this natural condition makes them a little bit nervous to give feedback toward its question. It happens because most English learners in Indonesia only practice English in the class and barely use it in daily life. Some observed that students could produce sentence accurately in a lesson, but could not use them appropriately when genuinely communicating outside of the classroom (Larsen-freeman and Anderson, 2011). Moreover, learning how to translate the language word by word or sentence without followed by regular practice to build a natural discourse also is a problem. Students may know the rules of linguistics usage but be unable to use the language (Widdowson 1978, as cited in Larsen-freeman and Anderson, 2011).

Moreover, Indonesia students also have difficulties while expressing their feeling directly into English. Its sequence is creating their own language and attempting to seek the proper vocabulary of those words in English, after that, they arrange those words into grammatically English. Those entire complicated processes caused them to feel difficult in uttering English and sometimes those sentences sound like broken English. This problem appears since they are not thinking in English but producing their own language and translating it into English. Thus, the learner gets their confusion because they have to switch the way they think in their own culture to another in which it is so tough. This phenomenon relates to the cultural factors which Byram and Morgan (1994) points out that learner cannot transform, or accommodate or even effectively assimilate into other cultures. They "cannot simply shake off their own culture and step into another"(Mukundan, 2005). The differences between learners and native speakers' cultures also one of the crucial problems, but it may be solved by giving them a new habit and created a new culture for them. Not only about linguistic features but also psycholinguistics feathers need to be understood. For example in Indonesia's context, when we compare an English proverb to Indonesian proverb, it may raise complicated interpretation to the students, since it is not only literal meaning but more completely close to the cultural aspect to describe. In natural conversation, it may appear, and if students translate the proverb directly to English the form will not get its meaning.

\section{Language and Culture in English Language Teaching}

In English language teaching, the role of the teacher is really crucial, it is really useful to help students by sharing their experience as former language learner as well (Larsenfreeman and Anderson, 2011). In this case, teachers are able to minimize students' obstacles in learning the language by exploring their own experiences as English students to avoid the Lınguısıs: Journaı or LInguıstıcs ana Language ı eacnıng Vol. 6, No. 2, December 2020 
same thing happen to their students. The teacher needs to focus on language as a complex unit during conducting the teaching and learning process, placing students in a proper position as the learner, and definitely understand who they are and what should be given to them. Non-linguistic competences of English also really influence students significantly; it becomes a major concern in language teaching. This is in line with Larsen-freeman and Anderson's (2011) view that teachers of language have thought about their subject matter what language and culture are; and for their students, teachers must be concern who they are as learners and how it is they learn. Therefore, a material design which included cultural contents, art, social politic, and history related to native English speaker will be also important.

In combining integrated material design, Lafayette (1988) suggests 9 ways in which language and culture can be integrated (Mukundan, 2005). Namely, (1) Cultural lessons and activities need to be planned as carefully as language activities and integrated into lesson plans; (2) Present cultural topics in conjunction with related thematic units and closely related grammatical content whenever possible. Use cultural contexts for language-practice activities, including those that focus on particular grammatical forms; (3) Use a variety of techniques for teaching culture that involves speaking, listening, reading, and writing skills. Do not limit cultural instruction to lecture or anecdotal formats; (4) Make good use of textbook illustrations and photos. Use probing questions to help students describe and analyze the cultural significance of photos and realia; (5) Use cultural information when teaching vocabulary. Teach students about the connotative meaning of new words, Group vocabulary into culture-related clusters; (6) Use small-group techniques, such as discussions, brainstorming, and role-plays, for cultural instruction; (7) Avoid the "facts only" approach by including experiential and process learning wherever possible; (8) Use the target language whenever possible to teach cultural content; and (9) Test cultural understanding as carefully as language is tested.

\section{DISCUSSION}

Some cultural issues in English language teaching probably do not get much concern in Indonesia. Still, there are some teachers who focus on how to teach students in mastering the language in structural form only; they focus on linguistic competence without considering the essence of language in the complex unit. The teacher must realize that language is not only about how to arrange a correct grammatical sentence but also how to use the language itself to the proper natural communication. The function of language tends to be communicative media in which focuses on delivering idea and content to the receiver and 
getting the feedback instead. Natural communication will run well if speaker's utterances are received clearly by listener and its idea also. As well as speaker, listener will give a respon as a sign that the listener gets its idea. The understanding between spaker and listener may indicate the proper natural communication.

When we elaborate on the common issue which may raise for English as a foreign learner in Indonesia, it relates to the lack of understanding of the essence of English as a part of culture and behavior. Students' obstacles in understanding English caused by the way they learn the language is complicated. As we know foreign language learners have their own mother tongue which had installed as their own basic language competence, this condition should be responded wisely. They have their own way to think and produce language in their culture and behavior. It means English is something new to them which totally different from their culture and behavior. As a result, English must be introduced as a culture, and new behavior to be known. Realizing that, it is not simple endeavor for teaching English to the learners who have their own mother tounge, because it is equal to give them a new culture. It can be considered that simplify the way how to learn the language in fun and interesting teaching material will open their mind. Giving more concern to the practical communication and cultural understanding also another way to teach them in a simple way. It is more effective than creating image that English is a bored grammatical form. Teachers are responsible to find an appropriate method or learning technique and create an enjoyable learning atmosphere that is interesting, active and fun (Maulana, 2020).

Integrated teaching material that covered linguistic and communicative competence, social and culture, and arts are definitely required. Providing topics of learning based on authentic sources from native English speaking countries such as fable, short story, conversation role-play, songs, movie, etc. will construct English learners more familiar to the relation between language and culture, they will understand where the relation derived from. Arranging integrated teaching material that covers listening, speaking, reading, and writing with included cultural or arts contents of English native speakers are an interesting way to bring to the class to relate both language and culture. An interesting topic discussion that lead them to get the essence of language and its culture will be a fascinating class to be joined. It will encourage students' interest naturally. It may be a beneficial impact from this concept to students and teachers as well. Prabhu (1992) as cited in Larsen-freeman and Anderson (2011) emphasizes that "if teacher engages in classroom activity with a sense of intellectual excitement, there is at least a fair probability that learner will begin to participate in the excitement and to perceive classroom lesson mainly as learning events- as experiences of growth for themselves". 
In addition, compiling proper teaching material which is based on the authentic source will be one of many ways to introduce the new culture to the students. For example, when the teacher gives a topic discussion about a short story, the content of its story including moral message, character, geographical image, and society will construct students' imagination related to what they learned, i.e., language. Now let us compare two different short stories in English language teaching in the Indonesian context, the short story of Cinderella and Timun Emas that have different cultural aspects in each other. The connection between English and Cinderella's story will be much easier to correlate than explaining the essence of two different cultures that is English and the story of Timun Emas. Then, explaining the story of Timun Emas probably will be easier to be gotten by students because it is their own culture, but we have to consider the objective of giving the authentic teaching material is to introduce a new culture, which is expected to be their habit and become familiar to them. Therefore, providing the local fairytale in English will not change their habit that is 'think in English and speak in English'. Now if we take Cinderella as a topic, students will get something new like the castle, Fairy Godmother, The Gown, and some other things not familiar to them which probably could not be found in Timun Emas. This is giving them some new knowledge and vocabularies including its culture's background. Further, the teacher also needs to provide the real picture or any other media to link the vocabulary and its image. This helps students to step by step create their unconscious habit that is 'think in English and speak in English'.

Delivering these materials gradually to students significantly will improve them through daily input by integrated teaching materials themselves. This concept will be expected as students' natural habit which means lead them to imitate the way native speakers produce English either spoken or written language. This will reduce English foreign students' problems while producing sentences in English. Most of them produce sentences in their own language followed by translated them into English. Learn how to think like native speakers will overcome this problem because students will think in English and expected to interpret their thought in English naturally without complicated translation mechanisms. All those things relate to the Sapir-Whorf theory that language is a part of culture and culture is people behavior, the way people think explained by their another statement that human being views the world by his own native language.

Widdowson (197S) and Siager (1978) emphasize the need for "context" and "longer, more natural discourse" as a basis for language teaching (Mukundan, 2005). Teachers have an obligation to set the teaching and learning circumstances as natural as possible. Context can be applied trough integrated teaching materials that contain culture and language aspects also correlate to the language used in daily life. While natural discourse can be applied 
through the daily basis of social interaction among students and teachers. In detail, the topic of teaching material is needed to build contextual learning, and relating teaching material to the real condition out of the class can be an image representation of language in daily use. Because sometimes what students have learned in the class will be much different from what is happening in real life. Furthermore, not only contextual teaching material that is important, but also practice in the whole occasion during teaching and learning process will construct a natural discourse. During social interaction out of teaching and learning context among students, the natural condition will create random situations and contexts that may not be found in organized class, it encourages them to arrange appropriate sentences related to the topic and situation. The ability to seek some proper vocabulary, pronunciation, and grammatically sentences sooner or later will improve students' language skills.

By considering strategies and plans that had been discussed above, those efforts are highly expected to improve students' skills and to minimize misunderstanding in English within their learning process. After introducing English and its culture, it may assist students to minimize their broken English to overcome. The awareness regarding the proper sentence in producing language will be solved by implementing suitable strategies and plans above to avoid the broken English in communication. This common mistake might be less raising appearing if the proper understanding of language and culture is given in the beginning. This the next sequence effect of complicated translation mechanisms in producing English. Due to focus on translation only, students neglect the appropriateness between vocabulary and context and it causes broken English. Therefore, by considering those issues students will be able to use the proper vocabularies toward its context in communication and avoid broken English.

When we look at the relation of providing the integrated teaching material and crossculture understanding toward English language teaching practice in Indonesia, it can be pointed out that improving students' communicative competence is one of the major objectives of English Language Teaching in Indonesia. Thus, the appropriateness in combining linguistic competence and communicative competence is definitely needed. Hence, Widdowson (1990) and Savignon (1997) state that this reason transforms the focus of teaching and learning language objective, such observations contribute to a shift in the field in the late 1970s and early 1980s from a linguistic structured-centered approach to a communicative approach (Mukundan, 2005).

\section{CONCLUSION}

Language and culture are two things unable to be separated from each other. They are supporting one another in terms of language learning and communicative competence. If the Lınguısıs: Journaı or LInguıstıcs ana Language ı eacnıng 
goal of language instruction is communicative competence, language instruction must be integrated with cultural and cross-cultural instruction (Celce-murcia \& Thurrell, 1995).Preparing integrated teaching material that contained cultural aspects, linguistics competence, the relation of language and communication, sociolinguistics, and social science are definitely required to support students in learning English. Proper teaching material which is based on the authentic source will be one of many ways to introduce the new culture to the students. Delivering these materials gradually to students significantly will improve their skill through daily input by integrated teaching materials themselves. The daily input should be followed by contextual learning and natural circumstances as language use in daily communication, so students' communicative competence will be improved. The communicative competence as objective should be drawn from linguistics, culture anthropology, sociolingistics, and other relevant areas of social science and humanities (Celce-murcia, 2007). Combination of those aspects will improve students' communicative competence and English language teaching in Indonesia.

\section{REFRERENCES}

Afriani, Z.L; Mirizon, S; Sitinjak, M. . (2020). Cultural Content Analysis of English Textbooks Used by Tenth Graders in Bengkulu Utara. LINGUA: JURNAL BAHASA DAN SASTRA, 20(1), 6576.

Celce-murcia, M. (2007). Intercultural Language Use and Language Learning (Eva Alcón Soler and Maria Pilar Safont Jordà, ed.). Dordrecht: springer.

Celce-murcia, M., \& Thurrell, S. (1995). Communicative Competence: A Pedagogically Motivated Model with Content Specifications. In Applied linguistic (Vol. 6).

Diane Larsen-freeman, and M. A. (2011). Technique \& Principle in Language Teaching (3rd editio). Oxford University Press.

Jafari, S. M. (2012). Language and Culture. International Journal of Humanities and Social Science, 2(17), 230-235.

Lafayette, R. (1978). Teaching Culture: Strategies and Techniques. In Language in Education: Theory and Practice. Center for Applied Linguistics.

Lafayette, R. (1998). Integrating the Teaching of Culture into the Foreign Language Classroom. In A. J. Singerman (Ed.), Toward a New Integration of Language and Culture. Reports of the Northeast Conference on the Teaching of Foreign Languages. VT: Northeast Conference I 988.

Maulana, A. (2020). NUMBER HEAD TOGETHER TECHNIQUE : ITS USE TO IMPROVE INDONESIAN EFL STUDENTS' READING ABILITY. Journal of English Teaching and Applied Linguistic, 1, 37-45. https://doi.org/https://doi.org/10.2020/jeta.v1i1.461

Mukundan, J. (2005). Bnglish Language Teaching Materials and Cross-Cultural Understanding: Are There Bridges. TEFLIN Journal, Volume XVI(1 Fbruari 2005), 42-53.

Nunn, R. (2002). Competence and Teaching English as an International Language. ASIAN EFL 
JOURNAL.

Roohul-Amini, M. (1989). Outline of Culture. Atar Press.

Zulianti, H., Maximilian, A., \& Ajeng, G. D. (2016). PENYULUHAN TENTANG PENTINGNYA PEMAHAMAN BUDAYA DALAM MENGAJAR BAHASA INGGRIS BAGI GURU-GURU BAHASA INGGRIS DI SMK PGRI 2 BANDAR LAMPUNG. Adiguna: Jurnal Pengabdian Dan Pemberdayaan Masyarakat, 1(2), 1-5. http://jurnal.stkippgribl.ac.id/index.php/adiguna/article/view/295 